\title{
Morphometric analysis and prioritization of Palathodi watershed in Parambikulam-Aliyar basin, Tamil Nadu using RS and GIS
}

\section{R. VINOTHKUMAR, S. ARUNVENKATESH, S. JANAPRIYA, M. RAJASEKAR AND I. MUTHUCHAMY}

Article Chronicle:

Received:

01.02.2016;

Revised :

24.04.2016;

Accepted :

07.05.2016

Key Words : GIS, Morphometric analysis, Soil erosion, Prioritization
ABSTRACT : The geomorphological characteristics of a watershed are more commonly used for developing the regional hydrological models for solving the various hydrological problems of the ungauged watersheds or inadequate data situations. Therefore, in this study morphometric analysis and prioritization of twenty one sub watersheds of palathodi watershed, which is tributary of ParambikulamAliyar river basin considered for this study. The morphometric parameters considered for analysis are stream order, stream length, stream frequency, drainage density, drainage texture, form factor, circulatory ratio, elongation ratio, constant channel maintenance, length of over land flow and compactness constant. After analysis of morphometric parameters compound parameter values are calculated and prioritization rating of twenty one sub watersheds is carried out. The sub watershed (Malumichampatti village) 4 has lowest compound parameter value 6.1 is likely to be subjected to a maximum soil erosion; hence, it requires immediate attention for provisions of soil conservation measures.

HOW TO CITE THIS ARTICLE : Vinothkumar, R., Arunvenkatesh, S., Janapriya, S., Rajasekar, M. and Muthuchamy, I. (2016). Morphometric analysis and prioritization of Palathodi watershed in ParambikulamAliyar basin, Tamil Nadu using RS and GIS. Asian J. Environ. Sci., 11(1): 51-58, DOI: 10.15740/HAS/AJES/ 11.1/51-58.
Author for correspondence : R. VINOTHKUMAR Department of Soil and Water Conservation Engineering, Tamil Nadu Agricultural University, COIMBATORE (T.N.) INDIA Email : kumar.nanthu@gmail. com

See end of the article for Coopted authors' 